\title{
CLAIMS ARISING FROM COMPENSABLE INJURIES TO LONGSHOREMEN AND HARBOR WORKERS: A TANGLED TRIAD OF REMEDIES*
}

The Longshoremen's and Harbor Workers' Compensation Act established a system of compensation for maritime injuries which balances the interests of both workers and employers more rationally than did the case law rules of tort liability. ${ }^{1}$ The act requires the employer, usually a stevedoring contractor, to pay compensation even when he might not have been liable for negligence. ${ }^{2}$ On the other hand, by limiting the employer's responsibility in all cases to an amount specified in the act, it decreases his liability in those cases in which previously he would have been answerable for negligence. ${ }^{3}$ An injured employee retains his right to hold third parties, usually the owner of the ship on which he was injured, liable in damages, even after the employer has volun-

*Czaplicki v. The Hoegh Silvercloud, 351 U.S. 525 (1956) ; Ryan Stevedoring Co. v. Pan-Atlantic S.S. Corp., 350 U.S. 124 (1956).

1. 44 Stat. 1424 (1927), 33 U.S.C. $\$ \$ 901-50$ (1952), as amended, Pub. L. No. $\$ 03$, S4th Cong., 2d Sess. (July 26, 1956). Representative Graham ( $\mathrm{Pa}$.) described the aims of the act as:

“. . to take out of litigation the vexatious conditions and defenses that interfered with the prosecution of claims of workmen injured in their work ... to equitably adjust all misfortunes attendant upon the work of any particular industry, and to put the burden of bearing that upon the industry, with an equitable adjustment of compensation."

68 Cong. Rec. 5410 (1927). The shifts in harbor workers' status prior to the act are complex. The benefits available under state workmen's compensation acts had been extended to harbor workers injured aboard ship until Southern Pac. Co. v. Jensen, 244 U.S. 205,217 (1917) held this application of the state statutes destructive of the uniformity in maritime matters intended by the Constitution. Congress, thereafter, twice amended the "saving to suitors' clause" of the Judiciary Act to include maritime workers within the scope of the state acts, Act of Oct. 6, 1917, c. 97, 40 STAT. 395, Act of June 10, 1922, c. 216,42 Staт. 634 , but both attempts were held unconstitutional delegations of legislative power. Knickerbocker Ice Co. v. Stewart, 253 U.S. 149 (1920); Washington v. W. C. Dawson \& Co., 264 U.S. 219 (1924). Harbor workers were thereupon held entitled to the benefits of the Merchant Marine Act, 1920 (Jones Act), 41 Stat. 1007, 46 U.S.C. § 688 (1952) giving to seamen an action at law against their employers for negligence and modifying the employer's common law defenses. International Stevedoring Co. v. Haverty, 272 U.S. 50 (1926). See Rorinson, Adniralty $\$ 39$ (1939). The passage of the Longshoremen's and Harbor Workers' Compensation Act in 1927 in effect nullified this extension. See note 3 infra and accompanying text. See also, for analysis of these shifts in harbor workers' status, Tetreault, Seamen, Seaworthiness and the Rights of Harbor Workers, 39 CoRnell L.Q. 381, 403-07 (1954); Comment, The Tangled Seine: A Survey of Maritime Personal Injury Remedies, 57 YaLE L.J. 243 (1947).

2. 44 STAT. 1426 (1927), 33 U.S.C. $\$ 904$ (1952).

3. 44 StAT. 1426 (1927), 33 U.S.C. $\$ \$ 904-10$ (1952). See, e.g., New York Cent. R.R. v. White, 243 U.S. 188, 203-04 (1917). 
tarily commenced compensation payments. ${ }^{4}$ But, to preclude double recovery. compensation ceases if the employee so elects." If the employee receives compensation under a formal award, his third-party cause of action is assigned to his employer. ${ }^{6}$ From any third-party recovery the employer recoups his cost of prosecuting the suit and the amount he is bound to pay the injured employee under the formal award of compensation; any excess is paid to the employee. ${ }^{7}$ Since the employer is usually better able financially to prosecute the suit, compensation under a formal award often works to the advantage of the employee. And, through the right of subrogation, the employer is safeguarded against compensating an employee for injuries primarily attributable to the negligence of others.

Three Supreme Court cases, however, have substantially altered the balance of interests effected by the act. The first, Seas Shipping Co. v. Sieracki, ${ }^{8}$ significantly increased the extent of shipowners' liability to longshoremen. Sieracki included longshoremen within the protection of an owner's absolute and nondelegable duty to provide "seamen" a seaworthy ship." and its rationale has been used to include other harbor workers as well. ${ }^{10}$ Hence a nonnegligent

4. 44 Stat. 1440 (1927), 33 U.S.C. $\$ 933$ (a) (1952) ; American Stevedores, Inc. v. Porello, 330 U.S. 446, 454-55 (1947) ; Jordan v. District of Columbia, 116 F. Supp. 559 (D.D.C. 1953). The act covers only employees injured while working on navigable waters of the United States. 44 Stat. 1426 (1927), 33 U.S.C. $\$ 903$ (a) (1952).

5. 44 Stat. 1440 (1927), 33 U.S.C. $\$ 933$ (a) (1952); The Owen, 43 F. Supp. 897,899 (E.D. Pa. 1942) ; cf. Aetna Life Ins. Co. v. Moses, 287 U.S. 530, 542 (1933). See also Chapman v. Hoage, 296 U.S. 526, 529 (1936) (employee who commences, but later terminates, suit may then obtain compensation if his conduct has not prejudiced the employer's right of subrogation) ; American Lumbermen's Mut. Cas. Co. v. Lowe, 70 F.2d 616, 618 (2d Cir. 1934) (same).

6. 52 STAT. 1168 (1938), 33 U.S.C. $\$ 933$ (b) (1952). For definition of a formal award see 44 Stat. 1435 (1927), 33 U.S.C. $\$ 919$ (c)-(e) (1952) ; Grasso v. Lorentzen, 149 F.2d 127, 128-29 (2d Cir.), cert. denied, 326 U.S. 743 (1945) ; Toomey v. Waterman S.S. Corp., 123 F.2d 718, 721 (2d Cir. 1941).

Under the act as originally passed a formal award was not a condition precedent to an assignment; if an employee accepted voluntary compensation the third-party cause of action vested in the employer. Longshoremen's and Harbor Workers' Compensation Act $\$ 33$ (b), c. 505, 44 StaT. 1440 (1927).

7. 52 Stat. 1168 (1938), 33 U.S.C. $\$ 933$ (e) (1952).

8. 328 U.S. 85 (1946).

9. Id. at 94; Mahnich v. Southern S.S. Co., 321 U.S. 96, 99, 100, 102 (1944); Carlisle Packing Co. v. Sandanger, 259 U.S. 255, 259 (1922). For a critical discussion of these characteristics of the seaworthiness doctrine see Tetreault, supra note 1, at 391-403.

10. Pope \& Talbott, Inc. v. Hawn, 346 U.S. 406, 412 (1953) (carpenter repairing unloading equipment). But see Berryhill v. Pacific Far East Lines, Inc., 238 F.2d 385 (9th Cir. 1956) (refusing inclusion of workman repairing "shaft keyway" because such not ship's work).

"Seaworthiness" is a term of art. Any inadequacy, under ordinary circumstances, of the ship's equipment, appliances or personnel will render it unseaworthy. Seas Shipping Co. v. Sieracki, 328 U.S. 85, 90 (1946) (equipment and appliances) ; Mahnich v. Southern S.S. Co., 321 U.S. 96, 103 (1944) (same) ; Boudin v. Lykes Bros. S.S. Co., 348 U.S. 336, 339 (1955) (personnel); Keen v. Overseas Tankship Corp., 194 F.2d 515, 519 (2d Cir.), 
owner may become liable to a maritime worker for a ship's unseaworthiness even if the defect was caused by a negligent employer. The shipowner, thereupon, may be forced to pay damages to an injured employee and, in effect, repay to the negligent employer that which he had expended in compensation. ${ }^{11}$

Shipowners have reacted to this increased responsibility by attempting to shift the burden of damages recovered by injured longshoremen to concurrently negligent employers. Precluded from obtaining any contribution from joint tortfeasors, ${ }^{12}$ they have relied upon contractual ${ }^{13}$ and quasi-contractual indemnity. ${ }^{14}$ Contractual indemnity presupposes an express or implied agreement between contracting parties that the promisor will save the promisee harmless from damages resulting from the former's improper performance of. the contract. Although express contracts of indemnity are not inconsistent

cert. denicd, 343 U.S. 966 (1952) (same). Recently the unseaworthiness doctrine has been applied to defects in equipment brought on board by and kept under the control of the employer. Alaska S.S. Co. v. Petterson, 347 U.S. 396 (1954), affirming 205 F.2d 478 (9th Cir. 1953) ; Rogers v. United States Lines, 347 U.S. 984 (1954), reversing 205 F.2d 57 (3d Cir. 1953).

11. Pope \& Talbott, Inc. v. Hawn, 346 U.S. 406, 412 (1953). The Court reasoned that a contrary result would frustrate the employer's statutory prerogative of reimbursement and constitute a species of contribution barred by Halycon Lines v. Haenn Ship Corp., 342 U.S. 282 (1952). See also Alaska S.S. Co. v. Petterson, supra note 10; Rogers v. United States Lines, supra note 10.

12. The leading case, Halcyon Lines v. Haenn Ship Corp., 342 U.S. 282, $285-87$ (1952), was predicated on the absence of an established right to contribution among joint tortfeasors in maritime, non-collision cases; the Court concluded that an extension of contribution would be better effected by Congress. Lower federal courts had previously assumed that contribution was available in admiralty, but differed as to the effect of the exclusive liability clause of the act. E.g., American Mut. Liab. Ins. Co. v. Matthews, 182 F.2d 322, 323 (2d Cir. 1950) (contribution barred because act relieved employer from common liability to injured employee) ; The S.S. Samovar, 72 F. Supp. 574, 589 (N.D. Cal. 1947) (contribution permitted because based on relationship between shipowner and employer). For a detailed review of federal cases see Weinstock, The Employer's Duty to Indemnify Shipowners for Damages Recovered by Harbor Workers, 103 U. PA. L. REv. 321, 323-28 (1954); see also state cases collected in Note, 42 VA. L. REv. 959 (1956).

13. American Stevedores, Inc. v. Porello, 330 U.S. 446 (1947) ; Brown v. AmericanHawaiian S.S. Co., 211 F.2d 16 (3d Cir. 1954) ; Barber S.S. Lines Inc. v. Quinn Bros., Inc., 104 F. Supp. 78 (D. Mass. 1952).

14. Quasi-contractual indemnification is a responsibility imposed by law, independent of contract, upon an active wrongdoer to indemnify a passive wrongdoer- when each is liable to the same third party. Shipowners have generally been denied recovery on this theory, since the necessary liability of the active wrongdoer, the employer, to the third party, the employee, has been negated by the act. Slattery v. Marra Bros., Inc., 186 F.2d 134, 139 (2d Cir.), cert. denied, 341 U.S. 915 (1951) ; Peak Drilling Co. v. Haliburton Oil Well Cementing Co., 215 F.2d 368, 370-71 (10th Cir. 1954); Brown v. AmericanHawaiian S.S. Co., 211 F.2d 16, 18 (3d Cir. 1954) ; American Mut. Liab. Ins. Co. v. Matthews, 182 F.2d 322, 324 (2d Cir. 1950). Contra, United States v. Rothschild Int'1 Stevedoring Co., 183 F.2d 181, 182 (9th Cir. 1950) ; Babnick v. The Mount Athos, 122 F. Supp. 68,73 (W.D. Wash. 1954). 
with the act, ${ }^{15}$ they are not customary; and employers consistently argue that the act precludes implied indemnity. ${ }^{16}$ For implying a contract of indemnity subjects the employer, without his consent, to liability to injured employees in excess of compensation which the act prescribes as the extent of his responsibility. ${ }^{17}$

The second case, Ryan Stevedoring Co. v. Pan-Atlantic Steamship Corp., ${ }^{18}$ rejected this argument and allowed a shipowner to recover from the employer on the theory of implied indemnity. An injured stevedore had elected to stue the shipowner for negligence rather than to recover compensation from his employer. Losing the suit to the employee, the shipowner sought to recover from the employer the amount it had paid. ${ }^{19}$ The Supreme Court decided that the employer's negligence in stowing cargo was a breach of its consensual "warranty of workmanlike service"20 and that the resulting damage, the injured employee's judgment against the shipowner, was a foreseeable consequence of the breach. ${ }^{21}$ Because the employer's liability was said to be based upon breach of contract with the shipowner, not upon negligence to the employee, the Court rejected the employer's claim to statutory immunity. ${ }^{22}$ The Court also rejected the employer's contention that the shipowner's failure to discover and correct the improper stowage barred indemnification. ${ }^{23}$ Although even an express contract of indemnity will not be construed to indemnify one against his own negligence unless such an intention is stated in unequivocal terms, ${ }^{24}$ the decision on this issue is in accord with a recognized exception allowing recovery when the indemnitee's negligence is merely the failure to discover and correct the consequences of the indemnitor's improper performance. $^{25}$

15. American Stevedores, Inc. v. Porello, 330 U.S. 446, 457 (1947) ; United States v. Arrow Stevedoring Co., 175 F.2d 329, 332 (9th Cir.), cert. denied, 338 U.S. 904 (1949); Green v. War Shipping Administrator, 66 F. Supp. 393, 395 (E.D.N.Y. 1946) ; Weinstock, supra note 12 , at $331,332$.

16. See Weinstock, supra note 12 , at $336-46$.

17. See note 3 supra and accompanying text; Brief for Petitioner for Writ of Certiorari, p. 10, Ryan Stevedoring Co. v. Pan-Atlantic S.S. Corp., 350 U.S. 124 (1956).

18. 350 U.S. 124 (1956). See Notes, 36 B.U.L. Rev. 312 (1956), 25 FordhaM L. Rev. 174 (1956); The Supreme Court, 1955 Term, 70 Harv. L. Rev. 83, 149; 3 U.C.L.A.L. REv. 669 (1956).

19. 350 U.S. at 127 .

20. Id. at 133 .

21. Id. at 130.

22. Id. at 131-32.

23. Id. at 134 .

24. Rice v. Pennsylvania R.R., 202 F.2d 861, 862 (2d Cir. 1953); Sinclair Prairie Oil Co. v. Thornley, 127 F.2d 128, 133 (10th Cir. 1942); Southern Bell Tel. \& Tel. Co. v. Mayor and Bd. of Aldermen, 74 F.2d 983, 984 (5th Cir. 1935).

25. Ryan appears to be the first case so holding since the exception was expressed by Mr. Justice Holmes in Boston Woven-Hose and Rubber Co. v. Kendall, 178 Mass. 232, 59 N.E. 657 (1901) and approved in Union Stock Yards Co. v. Chicago, B. \& Q.R.R., 196 U.S. 217, 228 (1905) (dictum). See also Mowbray v. Merryweather, [1895] 2 Q.B. 640, $642-43,646-47$ (C.A.). 
Ryan restores a measure of equilibrium to a situation weighted against the shipowner by Sieracki, by his inability to obtain contribution, and by employers' immunity under the act. It imposes upon employers, however, the same liability against which they were to be insulated by the act. Despite the technical niceties of the Court's position, the employer, through the shipowner, pays damages to an injured employee, although the act says that only compensation, limited in amount, shall be required. ${ }^{26}$

A practical effect of Ryan, moreover, is to devalue employees' statutory remedy against third-party tortfeasors. An employer, foreseeing a shipowner's claim to indemnity because of the employer's improper performance, ${ }^{27}$ could force the employee to a formal award. ${ }^{28}$ The act then vests the employee's third-party cause of action in the employer and thereby permits the employer, against whom the cause of action may ultimately be directed, to prosecute the suit ineffectively or even to elect not to prosecute. ${ }^{29}$ The Supreme Court, facing this result in Caaplicki v. The Hoegh Silvercloud, ${ }^{30}$ attempted to restore

26. The recovery in Ryan was $\$ 75,000$. Compensation and costs which the employer would be entitled to recoup totaled $\$ 12,797.36$. 350 U.S. at 127 . The maximum compensation allowable under the act is $\$ 17,280$. Pub. L. No. 803, 84th Cong., 2d Sess. (July 26, 1956).

27. Several commentators have suggested disclaimers. See 44 Calif. L. Rev. 800, 804 (1956) ; 25 FoRDHAM L. REv. 174, 177 (1956). However, the employer's bargaining position probably does not permit him, in a contract of service with a shipowner, to avoid the liability imposed by the decision.

28. Once an employee has filed a claim, the employer can easily obtain a final award. See 44 Stat. 1435 (1927), 33 U.S.C. $\$ 919$ (a)-(c) (1952); note 6 supra. Admittedly, the employee could fail to file a claim and sue the shipowner directly. It is unlikely, however, that the employee will make this election; if the suit against the shipowner is unsuccessful, he will have forfeited his right to compensation from the employer. Chapman v. Hoage, 296 U.S. 526, 529 (1936) (action by employee which would prejudice employer's subrogation rights against a third party would discharge the employer). Further, the injured employee's financial status is probably not such that he could elect not to file a claim.

29. If compensation after an award is paid by an insurance company, the latter is subrogated to the employer's assigned right of action against the shipowner. 52 STAT. 1168 (1938), 33 U.S.C. § 933(i) (1952). Compensation policies are normally written to cover employers impleaded by third parties against whom suit has been brought by an employee. Letter from Sidney A. Schwartz, counsel to Ryan Stevedoring $C_{0}$., Inc., to the Yale Law Jourmal, Nov. 9, 1956, on file in Yale Law Library. Insurance companies, therefore, are subject to the same conflict of interests as employers.

Ryan, moreover, spells the end of most employer's subsidies to employees conducting third-party suits, since to continue this practice would involve sponsoring lawsuits against themselves. 350 U.S. at 144 (dissenting opinion).

30. 351 U.S. 525 (1956). Czaplicki, longshoreman, had obtained a formal compensation award. His employer's insurer had paid the award, thereby becoming subrogated to the employee's causes of action against a marine contracting company and the shipowner, the former for negligence and the latter for negligence and unseaworthiness. The insurer did not move against the contracting company which it had insured. Nor did it move against the shipowner, since under the $R y a n$ case, the latter might have a right over against the employer, which it had also insured. Czaplicki then sued, inter alia, the shipowner and the contracting company, contending that the formal compensation award did not constitute an effective assignment of his causes of action. 
to the employee his statutory prerogative. The decision, however, is predicated upon ambiguous grounds and, regardless of how interpreted, fails to revitalize fully the employee's pre-Ryan position.

Czaplicki held that an injured employee could independently maintain a third-party suit after accepting compensation under a formal award ${ }^{31}$ if he were "the only person with sufficient adverse interest to bring suit."32 The Court, however, stated ". . . all that we hold is that, given the conflict of interests and inaction by the assignee, the employee should not be relegated to any rights he may have against the assignee, but can maintain the third-party action himself." 33 However, if the employer's inaction is a condition precedent to the employee's suit, the employer can retain complete control of the suit, despite any conflict of interests, and fail to prosecute it effectively. And, because the admiralty courts are open to him, ${ }^{34}$ he may so conduct it that the employee cannot intervene. ${ }^{35}$

In addition, even if the employee's capacity to maintain the third-party suit depends only upon a conflict of interests in the employer, the employer may nevertheless forestall the suit by compromising with the shipowner soon after

31. The Supreme Court's holding overturned a considerable body of contrary reasoning in the federal courts. See, e.g., Aetna Iife Ins. Co. v. Moses, 287 U.S. 530, 540 (1933) (act intended to effect a complete transfer of the cause of action) ; Moore v. Hechinger, 127 F.2d 746, 748 (D.C. Cir. 1942) (once compensation is accepted under an award the employee has no claim or right against any person responsible for his injury) ; Johnsen v. American-Hawaiian S.S. Co., 98 F.2d 847, 850 (9th Cir. 1938) (once employee has made a binding election he has no further control over the third-party suit); Moore v. Christiensen S.S. Co., 53 F.2d 299 (5th Cir. 1931) (upon payment of compensation employer alone can maintain third-party action); Hunt v. Bank Line, Ltd., 35 F.2d 136, 137 (4th Cir. 1929) (employee electing compensation has no further control over third-party suit, despite his interest in the proceeds) ; The Kokusai Kisen Kabushiki Kaisha, 44 F.2d 659, 660 (S.D. Tex. 1930) (employee's suit after assignment permitted only after employer's fraudulent refusal to sue). The Court's construction of the act, however, is not a repudiation of congressional intent, but is validated by a self-evident statutory pre-supposition that the interests of the assignee and employee would not be in conflict. $C f$. The Etna, 138 F.2d 37, 40 (3d Cir. 1943) ; The Supreme Court, 1955 Term, 70 Harv. L. Rev. 83, 150.

32. 351 U.S. at 531.

33. Id. at 532. (Emphasis added.)

34. Southern Pac. Co. v. Jensen, 244 U.S. 205 (1917) ; Atlantic Transp. Co. v. Imbrovek, 234 U.S. 52, 60 (1914); Sieracki v. Seas Shipping Co., 149 F.2d 98, 99 (3d Cir. 1945), aff'd, 328 U.S. 85 (1946).

35. Admiralty courts have jurisdiction over maritime torts in personam as well as in rem. See Munro v. Almeida, 23 U.S. (10 Wheat.) *473, *486 (1825); Czaplicki v: The Hoegh Silvercloud, 351 U.S. 525, 527 (1956) (action in personam and in rem for alleged negligence and unseaworthiness); Mahnich v. Southern S.S. Co., 321 U.S. 96, 97 (1944) (liability in personam for unseaworthiness). See also AdMIRALTy RuLE 15 (restricting suits for assault or beating to actions in personam). Third parties may not intervene in in personam admiralty proceedings. ADMIRALTY RuLes 34, 42 ; The Oregon, 158 U.S. 186, 210 (1895) ; Geotechnical Corp. v. Pure Oil Co., 196 F.2d 199, 206 (5th Cir.), ccrt. denied, 344 U.S. 879 (1952) ; Defense Plant Corp. v. United States Barge Lines, 145 F.2d 766, 767 (2d Cir. 1944). 
the formal award. ${ }^{36} \mathrm{~A}$ settlement is often likely, since each party can benefit by compromise. The employer's maximum return under an assignment of the employee's claim is limited by statute to compensation and costs, and is thus the same from both compromise and damage action; $; 3$ but the employer may lose much more in a suit than by compromise, since he always has some risk of liability on an implied indemnity. The shipowner, aware of this weakness in the employer's bargaining position, will usually be able to obtain a relatively small settlement. The settlement will then bar the employee from suing the shipowner under the Czaplicki doctrine, ${ }^{38}$ unless the court finds that an "adverse interest" is a prerequisite to a valid compromise, as it was in Caaplicki to the employer's right to prosecute an action against the shipowner. If the employer were liable to the shipowner as an indemnitor, he would certainly lack a sufficient adverse interest. But even under this rationale, the employee would probably be forced to litigate the complex and as yet undefined issue of indemnity under Ryan, ${ }^{39}$ a question only peripheral to his damage action.

The statutory balance of liability could be preserved by eliminating the shipowner's liability to longshoremen for unseaworthiness when the defect arose solely through the employer's failure to perform properly. ${ }^{40}$ Eliminating the shipowner's liability in this situation would restore to the employer most of

36. After the assignment effected by a formal award the act permits the employer to compromise without the employee's consent. 44 STAT. 1440 (1927), 33 U.S.C. $\$ 933$ (d) (1952).

37. 52 StaT. 1168 (1938), 33 U.S.C. \$ 933(e) (1952).

38. The Court, in Craplicki, specifically declined to characterize the assignee as a fiduciary. 351 U.S. at 532. See Title G. \& T. Co. v. Mortgage Comm'n, 273 N.Y. 415, 426,7 N.E.2d 841, 846 (1937) (in case of assignment there is no fiduciary relationship between assignor and assignee); 1. ScorT, Trusts 152, 154 (1956) (same). Since the act permits the employer to compromise the third-party claim without the consent of the employee, it is doubtful that Congress intended a fiduciary relationship. 44 STAT. 1440 (1927), 33 U.S.C. \& 933 (d) (1952). But see United States Fidelity \& Guarantee Co. v. United States, 152 F.2d 46, 48 (2d Cir. 1945) (assignee under the act is, in effect, a trustee who "must not ... entirely disregard the employee's interest"), endorsed by the dissenting opinion in Caaplicki, 351 U.S. at 535. Should the assignee be considered a fiduciary, any compromise made in which his possible liability as indemnitor was a factor would seem a breach of trust for which he would be held responsible to the employee. See 2 ScotT, TRUSTs 150 (1956).

39. In Connolly v. Weyerhauser S.S. Co., 236 F.2d 846 (2d Cir. 1956), for instance, the majority found Ryan inapplicable because the employee's injury was not a foreseeable consequence of the employer's negligence; the dissenting opinion thought Ryan controlling because the shipowner's intervening negligence, although active and unforeseeable, was not a proximate cause of the injury. In Seawright v. A. Garcia Y Cia., 138 F. Supp. SS1, 884 (E.D. Pa. 1956), the court reasoned that the jury, having found shipowner negligent, must determine on remand: whether his negligence was primary or secondary; whether it was active or passive; and the relationship of his negligence to employer's conduct, in order to find legal cause.

40. See notes 24-25 supra and accompanying text. 
the immunity granted by the act. ${ }^{41}$ And since this immunity abrogates the employer's conflict of interests, such a partial repeal of the Sicracki doctrine would also abrogate his incentive to impede the employee's third-party suit for unseaworthiness. ${ }^{42}$

A more realistic solution would repeal the Sieracki rationale entirely and deny the application of the unseaworthiness doctrine to longshoremen. Longshoremen, who board a ship only in port and never venture to sea, are subject to totally different conditions, and do not need the protection granted to seamen of an absolute liability rule. ${ }^{43}$ Shipowners should therefore be liable to longshoremen only for negligence. This was the extent of liability of third parties to longshoremen when the act was passed, ${ }^{44}$ and, presumably, an action for negligence was the only type of third-party claim which the act intended to preserve. If the Sieracki doctrine were rejected, ${ }^{45}$ the tendency of the Ryan

41. For the single situation in which the employer could still be held liable for negligence under Ryan, see text at note 46 infra.

42. The employee, however, would have a heavier trial burden when faced with the defense that unseaworthiness, if it existed, was caused solely by the employer.

43. Sieracki was vigorously criticized in the dissenting opinion, 328 U.S. at 103-08, and has been since. See Pope \& Talbott, Inc. v. Hawn, 346 U.S. 406, $422-26$ (1953) (dissenting opinion); Tetreault, supra note 1, at 382; Ambler, Seamen Are "Wards of the Admiralty" but Longshoremen Are Now More Privileged, 29 WASH. L. REv. 243, 257 (1954); Dickinson \& Andrews, A Decade of Admiralty in the Supreme Contrt of the United States, 36 Calif. L. Rev. 169, 191. (1948); Notes, 102 U. PA. L. REv. 402, 404 (1954) ; 34 Calif. L. Rev. 601 (1946) ; 45 Colun. L. Rev. 957 (1945) ; 59 Harv. L. Rev. 127 (1945). The Washington representative of the International Longshoremen's and Warehousemen's Union recently expressed disapproval of Sieracki because it undermined the original quid pro quo of the act. Hearings Before a Special Subcommittee on Bills Relating to the Longshoremen's and Harbor Workers' Compensation Act (Third Party Liability) of the House Committee on Education and Labor, 84th Cong., 2d Sess. at 97-99 (1956). Seamen, moreover, are expressly excluded from the Longshoremen's and Harbor Workers' Compensation Act, 44 STAT. 1425 (1927), 33 U.S.C. \$ 902(3) (1952), and are not included in any other compensation plan. RoBINson, ADMIRALTY $\$ 39$ (1939).

44. Ambler, supra note 43, at 257; The Supreme Court, 1955 Term, 70 Harv. L. Rev. 83,150 .

45. A common-law cause of action may be abolished by statute to effect a proper legislative end. Silver v. Silver, 280 U.S. 117, 122 (1929) ; Martin v. Pittsburg \& L.E. R.R., 203 U.S. 284, 295 (1906) ; Munn v. Illinois, 94 U.S. 113, 134 (1876).

H.R. 111.13 and 11119, 84th Cong., 2d Sess. (1956), identical bills, proposed the rejection of Sieracki, but were unfortunately coupled with provisos which removed third-party suits arising under the Longshoremen's and Harbor Workers' Compensation Act from the "saving to suitors' clause" of the Judiciary and Judicial Procedure Act, 28 U.S.C. $\$ 1333$ (1) (1952), and established contributory negligence as an absolute defense in derogation of the admiralty rule of comparative negligence. The Max Morris, 137 U.S. 1, 14 (1890). See also Garrett v. Moore-McCormack Co., 317 U.S. 239, 243 (1942) (admiralty rights enforced by common-law courts). These propositions, in addition to encroaching unjustifiably upon longshoremen's and harbor workers' time-honored prerogatives, have been attacked as arbitrary classifications unconstitutional under the due process clause of the Fifth Amendment. Hearings, supra note 43, at 17-19. See also Bolling v. Sharpe, 347 U.S. 497, 499 (1954) ; Detroit Bank v. United States, 317 U.S. 329, 338 (1943); Steward Mach. Co. v. Davis, 301 U.S. 548, 584-85 (1937). 
rationale to pinch the employer's statutory immunity would be diminished. Shipowners would not be liable to employees unless negligent. Employers would be liable to negligent shipowners on an implied indemnity theory only if, as in Ryan, the negligence of the shipowner were merely the failure to discover and correct the consequences of the employer's improper performance. ${ }^{46}$

Congressional opposition to higher compensation levels indirectly blocks what seems the most desirable path to a satisfactory balance: the inclusion of shipowners within the compensation system of the act. ${ }^{47}$ Under such a plan owners, presently liable without fault for the unseaworthiness of their ships, would receive a fixed limit on liability. Employers' immunity from damages under the act, intended to be complete, would become complete. ${ }^{48}$ Insurance in the field could be written on a more rational basis; presently, under Ryan, employers are subject to risks of liability which defy safe actuarial computation. ${ }^{49}$ If shipowners were included within the compensation scheme of the act and were required to share compensation payments with employers on a predetermined basis, the liability of each could be easily insured. In addition, shipowners' resources, now subject to large damage suits by a few injured employees, would be available to increase, without hardship, the level of compensation for all injured employees. It is doubtful, however, that such increases would materialize. Many Congressmen viewed the levels of compensa-

46. See note's 24-25 supra and accompanying text.

47. Since Crowell v. Benson, 285 U.S. 22, 56 (1932), held that the constitutionality of the act depended upon the existence of the master and servant relation, a compensation system which categorically includes shipowners might be thereby suspect. However, as Justice Brandeis observed in his dissenting opinion, $\S 4(a)$ of the act itself provides for the inclusion of the shipowner if the employer has not assured payment of compensation. Id. at 83. See 1 Larson, Wormaren's Compensation $\$ 49.22$ (1952); Schwartz, Does the Ghost of Crowell v. Benson Still Walk, 98 U. PA. L. Rev. 163, 171 (1949); Note, 46 HAARv. L. Rev. 478, 488 (1933). At least five states, moreover, impose liability on the general contractor to pay compensation to an employee of a subcontractor, even if the subcontractor is able to make payment. Conn. Gen. Stat. \$ 7423 (1949) ; Fla. Stat. AnN. $\$ 440.10$ (Supp. 1955) ; Kan. Gen. Stat. Ann. c. 44, \& 503 (Supp. 1955) ; LA. Stat. ANN. \$ $23: 1061$ (Supp. 1955) ; MD. Ann. Cone art. 101, $\$ 63$ (Supp. 1955). These provisions have been held constitutional. Seabury v. Arkansas Natural Gas Co., 171 La. 199, 130 So. 1 (1930) ; Maryland v. Bennett Bldg. Co., 154 Md. 159, 140 Atl. 52 (1928). The latter case upheld the Maryland statute because it required both the general contractor and the employee of the subcontractor to yield some part of their respective rights. Despite Sicracki shipowners have something left to yield. See Berryhill v. Pacific Far East Lines, Inc., 238 F.2d 385 (9th Cir. 1956) (restricting scope of warranty of seaworthiness to those engaged in activity traditionally considered ship's work). Cf. NLRB v. Hearst Publications, Inc., 322 U.S. 111, 124 (1944) (approving application of National Labor Relations Act beyond the "immediate technical relation of employer and employee").

48. S. Kep. No. 973, 69th Cong., 1st Sess. 16 (1926).

49. Yancey, Shoreside Maritime Workers and The Warranty of Seaworthiness, 22 INs. Counser J. 95, $98-99$ (1955). The judgment against Ryan Stevedoring Co., for instance, was $\$ 75,000$, note 26 supra, and its insurance coverage only $\$ 25,000$. Reply Brief for Petitioner to that of the United States, as Amicus Curiae, p. 4 n.3, Ryan Stevedoring Co. v. Pan-Atlantic S.S. Corp., 350 U.S. 124 (1956). 
tion set in $1956^{50}$ as low for longshoremen. ${ }^{51}$ But the act now regulates federal compensation for nongovernment employees, ${ }^{52}$ and it was said that a compromise therefore had to be made with the lower wage scales prevalent in the District of Columbia. ${ }^{53}$ The objection does not seem particularly well taken, however; even if longshoremen and workers in the District must be governed by the same act, ${ }^{54}$ a percentage of the individual's wage rate is prescribed as a maximum on compensation recovery, regardless of the absolute dollar maximum. ${ }^{55}$ Should, however, the congressional attitude toward higher benefits change, the inclusion of shipowners in the compensation system would provide the most rational balance to the diverse interests of workers, employers, and shipowners.

In any event, the act should be amended to require compensation payments during the prosecution of a third-party action by the employee and to eliminate the assignment of that action to the employer after a formal award. ${ }^{50} \mathrm{Em}$ ployees, at present dependent upon inadequate compensation, ${ }^{57}$ should at least

50. Pub. L. No. 803, 84th Cong., 2d Sess. (July 26, 1956).

51. 102 Cong. Rec. 11528, 11529, 11530, 11535, 11543 (daily ed. July 13, 1956). Compensation benefits under the act have been criticized as generally inadequate. See REEDE, Adequacy of Workmen's CoMrensation 66, 67, 85, 89 (1947); Bean, Choice of Remedies by Injured Maritime Workers, 1 NACCA L.J. 74, 77 (1948).

52. Act of May 17, 1928, c. 612, 45 Star. 600 (employees in the District of Columbia); 55 StAT. 622 (1941), 42 U.S.C. $\$ 1651$ (1952) (employees at military bases outside the United States); 56 Stat. 1031 (1942), 42 U.S.C. \$ 1702 (1952) (workers hired by government contractors performing outside the United States).

53. 102 Cong. Rec. 11528 (daily ed. July 13, 1956).

54. See debatc, id. at 11532-43.

55. 44 Stat. 1427 (1927), 33 U.S.C. § 908 (1952).

56. A similar proposal, an adaptation of N.Y. WorkMEN's CoMp. LAw $\S 29$, was made in H.R. 5357, 84th Cong., 1st Sess. (1955). According to this bill, however, if the employer sued, the employee would receive only two-thirds of the excess over compensation and costs of recovery gained by the employer. The bill's proponents justify the employer's retention of the remainder as a needed incentive to vigorous prosecution of the claim and, necessarily in the alternative, as a limit on the employer's attorney's fees. Hearings, supra note 43 , at $13,19,46,47$. The limitation of attorney's fees rationale envisages no enrichment of the employer, but rests upon a misapprehension of New York law, that the employer's attorney's fees are not deducted prior to the determination of the amount of excess available for distribution. $I d$. at 46 . New York law would seem to be contrary. Lappin v. National Container Corp., 179 Misc. 109, 112, 37 N.Y.S.2d 800, 803 (Sup. Ct. 1942). It would seem also that adequate incentive is provided the employer by permitting him to recover his compensation outlay. See Hearings, supra note 43 , at 44 . Only two states allow the employer more. 2 LARSON, WORKMEN'S COMPENSATION $\$ 74.31$ (1952). And to permit the employer to retain one-third of the excess would present the anomalous possibility of a tortfeasor materially profiting by his own negligence when the employer and shipowner were joint tortfeasors.

For other variations of the employee-priority type assignment statute see FLA. STAT. ANN. $\$ 440.39$ (4) (Supp. 1955) (assignment if employee fails to bring suit for one year); IrL. ANN. Stat. c. 48, $\$ 138.5$ (Supp. 1956) (assignment if employee fails to bring suit prior to three months before action barred by statute of limitations).

57. See note 51 supra. 
have full opportunity to take advantage of available remedies against thirdparty tortfeasors. ${ }^{\text {"s }}$ This amendment would end the employer's opportunity to gain control of the third-party action by controverting the employee's compensation claim. Moreover, employees proceeding against third parties would be subsidized by deserved compensation, rather than by fortuitous employer beneficence. 59 To preclude the employee's double recovery and to preserve the employer's prerogative of reimbursement the act should also be amended to give to the employer a lien on the proceeds of any third-party recovery to the extent of the total amount of compensation awarded, provided, or estimated. In order to permit the employer to recoup his costs and compensation payments should the employee be unwilling to prosecute, the third-party action should vest in the employer within a fixed, but relatively lengthy, period after compensation commences. ${ }^{B 0}$ These changes, enacted without concurrent rejection of Sicracki or the inclusion of shipowners within the statutory compensation scheme, admittedly would leave employers defenseless against the full effect of Ryan. This seems preferable, however, to the present adjustment of liability between shipowners and employers which, without providing increased compensation benefits, severely curtails injured employees' statutory rights to hold third parties liable in damages.

58. Should shipowners be included within the compensation system of the act, this amendment would enable employees to prosecute other third-party tortfeasors without being subject to the disabilities inherent in the present act.

59. See note 29 supra.

60. The period is six months in New York. N.Y. WorkMEN's Comp. Law $\$ 29$. See also statutes cited note 56 supra. 